\title{
PENGARUH KUALITAS PELAYANAN, CITRA MEREK, DAN ELECTRONIC WORD OF MOUTH (E-WOM) TERHADAP KEPUASAN PELANGGAN GRAB FOOD DI BALI PADA MASA PANDEMI COVID-19
}

\author{
P. D. A. Pratama1, Nym. Yulianthini ${ }^{2}$ \\ 1,2 Jurusan Manajemen, Universitas Pendidikan Ganesha, Singaraja \\ e-mail: putudioarthapratama@undiksha.ac.id, nyoman.yulianthini@undiksha.ac.id
}

\begin{abstract}
Abstrak
Studi berikut dimaksudkan untuk menguji pengaruh kualitas pelayanan, citra merek, serta electronic word of mouth (E-WOM) yang ditujukan pada kepuasan pelanggan. Studi berikut menggunakan desain kuantitatif yang bersifat kausal. Pada penelitian ini, subjek berasal dari Pelanggan Grab food di Bali pada masa pandemi COVID-19 dan objek penelitian ialah kualitas pelayanan, electronic word of mouth (E-WOM), citra merek, dan kepuasan pelanggan. Kuesioner dan pencatatan dokumen dimanfaatkan untuk mengumplkan data kemudian dianalisis melalui analisis regresi linier berganda. Adapun hasil yang diperoleh yakni (1) Kualitas pelayanan, citra merek dan electronic word of mouth (E-WOM) memiliki impak yang signifikan dan positif terhadap kepuasan pelanggan Grab Food, (2) kualitas pelayanan memiliki impak yang signifikan dan positif terhadap kepuasan pelanggan, (3) citra merek memiliki impak yang signifikan dan positif terhadap kepuasan pelanggan, dan (4) electronic word of mouth (E-WOM) memiliki impak yang signifikan dan positif terhadap kepuasan pelanggan pada pelanggan Grab Food di Bali Pada Masa Pandemi COVID-19.
\end{abstract}

Kata kunci: Citra Merek, Electronic Word of Mouth (E-WOM), Kepuasan Pelanggan, Kualitas Pelayanan,

\begin{abstract}
This study was proposed to investigate the effect of service quality, brand image, and electronic word of mouth (E-WOM) on customer satisfaction. Thls study was using quantitative design which had causal characteristic. In this research, the subjects came from the Grab Food customers in Bali during the COVID-19 pandemic and the objects of the research were service quality, electronic word of mouth (W-WOM), brand image, and customer satisfaction. Questionnaire and document recording were used to gather the data and then analyzed through multiple linear regression analysis. The results portrayed that (1) service quality, brand image and electronic word of mouth (E-WOM) have a significant and positive influence toward Grab Food customer satisfaction (2) service quality has a significant and positive influence toward customer satisfaction, (3) brand image has a significant and positive influence toward customer satisfaction, and (4) electronic word of mouth (E-WOM) has a significant and positive influence toward customer satisfaction for Grab Food customers in Bali during the COVID-19 Pandemic.
\end{abstract}

Keywords: Brand Image, Customer Satisfaction, Electronic Word of Mouth (E-WOM), Service Quality.

\section{Pendahuluan}

COVID-19 merupakan wabah penyakit sindroma pernafasan akut, yang mulai awal tahun 2020 menyebar hampir ke seluruh dunia dan mengakibatkan terpuruknya kondisi ekonomi dunia. Pesatnya perkembangan pada pandemi COVID-19 ini membawa dampak signifikan terhadap perubahan perilaku dan kebiasaan masyarakat karena menerapkan social distancing. Salah satu bidang yang membantu masyarakat untuk menerapkan social distancing adalah transportasi online yang saat ini para pelaku transportasi online memudahkan konsumen dalam layanan pembelian makanan dengan menyediakan fitur pengantaran makanan.

Salah satu contoh aplikasi transportasi online yang banyak digunakan adalah Grab, dimana Grab memiliki fitur Grab Food yang merupakan fitur pengantaran makanan, fitur ini membantu masyarakat dalam menerapkan social distancing karena Grab Food menjalankan sistem pengantaran makanan tanpa kontak. Dalam proses menjalankan sistem pengantaran makanan perlu diperhatikan hal-hal yang menjadi kebutuhan, kemauan atau keinginan 
pelanggan agar pelanggan tidak kehilangan rasa puas pascapenggunaan jasa Grab Food. Maka dari itu, perlu untuk mengenali aspek-aspek yang mengenakan pengaruh pada kepuasan pelanggan terhadap platform transportasi online Grab pada saat melakukan pembelian makanan menggunakan Grab Food pada masa pandemi ini.

Menurut (Kotler \& Philip, 2001), rasa puas pelanggan merupakan tingkat kecocokan seorang konsumen pasca melakukan perbandingan pada produk atau jasa yang dipakai dengan ekspektasinya terhadap jasa atau produk terkait. Rasa puas konsumen juga mampu diartikan sebagai seorang pelanggan yang mengalami keadaan puas atau tidak puas, setelah melakukan perbandingan pada performa suatu produk yang dipakai (hasil) dalam koneksinya dengan ekspektasi konsumen tersebut (Lin, Chen, \& Chiu, 2010). Berdasarkan (Irawan, 2010), tanda yang menunjukkan rasa puas pelanggan ialah 1) Perasaan puas dari pelanggan saat mendapat servis yang memuaskan dan barang yang berkualitas dari produsen, 2) Konsumen akan secara berkelanjutan menggunakan dan terus melakukan aksi pembelian pada suatu barang jika terpenuhinya ekspektasi yang mereka dambakan, 3) Akan memberi rekomendasi kepada konsumen lain, dan 4) Tercapainya ekspektasi konsumen pasca-pembelian atau penggunaan barang atau jasa.

(Lahap, Ramli, Said, Radzi, \& Zain, 2016) mengungkapkan brand image memberikan impak rasa puas pada konsumen. Rasa puas konsumen dikenakan pengaruh oleh Technology Acceptance Model serta Electronic Word of Mouth. (Martina \& Sitio, 2019) mengungkapkan bahwa kualitas servis, kualitas barang, dan pemasaran dari keputusan pembelian memiliki impak yang baik pada rasa puas pelanggan. Hal ini selaras dengan Pasaribu (2019) yang menyerukan bahwa Electronic Word of Mouth memiliki impak yang baik pada rasa puas konsumen. (Nastiti, Rahayu, \& Astuti, 2019) menyampaikan bahwa persepsi harga, citra merek, dan kualitas layanan memiliki impak yang baik pada rasa puas konsumen. Begitu pula yang disampaikan oleh (Bahtiar, Laba, \& Jusni, 2019) yang mengungkapkan bahwa marketing mix dan service quality memiliki impak yang baik pada rasa puas konsumen. Sejalan dengan pendapat ahli sebelumnya, studi yang dilaksanakan oleh (Nainggolan \& Hidayat, 2020) mengungkapkan bahwa Country Of Origin, brand image, price fairness and service quality mempunyai impak yang baik pada rasa puas konsumen sehingga dapat ditarik sebuah inti sari bahwa rasa puas konsumen telah diberikan pengaruh oleh sejumlah variabel yang bervariasi, tetapi dalam studi ini hanya memperhatikan penggunaan variabel kualitas layanan, citra merek, dan electronic word of mouth (E-WOM) yang ditujukan pada kepuasan konsumen.

Kualitas servis atau pelayanan merupakan pemberian nilai oleh konsumen yang ditujukan pada proses pemberian layanan yang telah dialami oleh konsumen. Berdasarkan pendapat dari (Nastiti et al., 2019), kualitas sebuah servis ialah tingkat evaluasi yang didapatkan oleh konsumen kemudian dilakukan perbandingan dengan apa yang pembeli berikan demi memperoleh jasa atau barang terkait. Kualitas sebuah servis menawarkan peran yang signifikan untuk produsen. Merujuk pada jasa yang ditawarkan, dengan kualitas servis yang diekspektasikan oleh konsumen mampu menawarkan tingkat rasa puas pembeli yang menjanjikan. Konsumen tidak hanya memberi penilaian berdasarkan hasil yang diberikan, namun juga dari proses pemberian jasa terkait (Noerchoidah, 2017).

Kualitas servis pada studi ini dinilai melalui lima poin indikator (Parasuraman \& Berry, 1988) yakni 1) Tangibles atau bukti laagsung adalah kecakapan sebuah produsen saat mempresentasikan keberadaannya ke khalayak luar, 2) Reliability atau keandalan merupakan kecakapan produsen dalam menawarkan servis yang selaras dengan apa yang dijanjikan dalam tingkat akurasi yang mantap dan dapat dipercaya, 3) Responsiveness atau ketanggapan ialah sebuah regulasi demi membantu dan menawarkan servis yang akseleratif, responsif, serta tepat untuk konsumen melalui pemberian info yang gamblang, 4) Assurance atau jaminan adalah wawasan tentang tata krama dan kesantunan, serta kecakapan para pekerja dari produsen dalam mengembangkan kepercayaaan para konsumen kepada produsen, dan 5) Empathy atau empati adalah penawaran atensi yang sungguh-sungguh dan memiliki sifat pribadi yang ditawarkan ke para konsumen dengan melakukan upaya seperti mengerti ekspektasi pelanggan.

Citra merek ialah pandangan tentang rasa percaya yang dimiliki oleh konsumen terhadap sebuah produk maupun jasa. Menurut (Ferrinadewi, 2008), citra merek adalah istilah 
yang dibuat oleh konsumen bukan berdasarkan alas an objektif dan berdasarkan perasaan individual. Image dari sebuah barang atau jasa dapat menawarkan pandangan khusus pada pelanggan (Nastiti et al., 2019). Faktor yang memengaruhi citra merek berdasarkan pendapat (Ratri, 2007) yakni 1) Product attribute atau atribut produk, adalah berbagai aspek yang memiliki hubungan dengan brand terkait, seperti bungkus, harga, rasa, dan lain-lain, 2) Consumer benefits atau keuntungan pelanggan, ialah fungsi barang dari brand tertentu, dan 3) Brand personality atau sifat merek, adalah keutuhan yang berkaitan dengan sifat suatu brand jika merek tersebut merupakan manusia.

Electronic word of mouth merupakan suatu pemberitaan yang baik maupun buruk yang dilaksanakan oleh konsumen yang memiliki potensi maupun konsumen terdahulu yang tidak menetap tentang barang atau suatu tempat produksi, yang diperuntukan untuk publik atau badan khusus dari media daring (Hennig-Thurau, Gwinner, Walsh, \& Gremler, 2004). Pada masa ini, Word of Mouth tak hanya mampu dilaksanakan melalui pertemuan langsung langsung dengan orang yang akan merepresentasikan hal terkait. Namun, juga mampu dilaksanakan melalui pemanfaatan fasilitas daring atau yang diistilahkan sebagai Electronic Word of Mouth, yang menyebabkan penambahan jumlah pengguna system daring dan media social yang berperan signifikan.

Faktor penunjuk E-WOM berdasarkan (Hennig-Thurau et al., 2004) yakni 1) Motif platform assistance ialah rasa percaya yang dimiliki oleh pelanggan pada media yang dipakai, 2) Motif venting negative feelings adalah harapan untuk menyampaikan rasa ketidaksesuaian pelanggan pada barang atau tempat produksi 3) Motif concern for other consumers ialah harapan yang sungguh-sungguh dalam menawarkan rekomendasi ke pelanggan lain, 4) Motif extraversion/positive self-enhancement ialah harapan pelanggan untuk menyebarkan pengalaman penggunaan mereka untuk menambah image sebagai pelanggan yang pintar, 5) Motif social benefits adalah harapan untuk menyebarkan berita dan berkomunikasi dengan lingkungan sosial, 6) Motif economic incentives adalah harapan untuk mendapatkan keuntungan dari tempat produksi, 7) Motif helping the company adalah harapan pelanggan untuk memberi bantuan pada tempat produksi dan 8) Motif advice seeking adalah harapan untuk menemukan saran dan rekomendasi dari pelanggan terdahulu.

Studi ini dimaksudkan untuk mengetahui: 1) Pengaruh Kualitas Servis atau Layanan, Citra Merek dan Electronic Word of Mouth yang ditujukkan pada Kepuasan Konsumen Grab Food, 2) Pengaruh Kualitas Pelayanan terhadap Kepuasan Pelanggan Grab Food, 3) Pengaruh Citra Merek yang ditujukan pada Rasa Puas Pelanggan Grab Food, dan 4) Pengaruh Electronic Word of Mouth terhadap Kepuasan Pelanggan Grab Food.

\section{Metode}

Studi berikut dilakukan demi mengenali impak dari kualitas pelayanan, citra merek, dan electronic word of mouth terhadap kepuasan pelanggan pada Grab Food di Bali pada masa pandemi COVID-19. Subjek pada studi berikut adalah pelanggan Grab Food di Bali pada masa pandemi COVID-19 dan objek penelitiannya adalah kualitas pelayanan, citra merek, electronic word of mouth serta kepuasan pelanggan. Studi ini didesain sebagai penelitian kuantitatif.

Studi ini menggunakan pelanggan Grab Food di Bali pada masa pandemi COVID-19 sebagai populasi. Studi berikut merupakan studi sampel. Metode penentuan sampel yang digunakan pada studi berikut adalah metode purposive sampling. Purpose sampling adalah teknik penentuan sampel dengan melakukan penghitungan tertentu (Sugiyono, 2011). Sampel pada studi ini dipilih berdasarkan kriteria-kriteria yakni: (1) Pelanggan Grab Food di Bali pada masa pandemi COVID-19. (2) Pelanggan Grab yang melakukan pembelian makanan menggunakan Grab Food minimal 1 kali dan lebih dari 2 kali pada masa pandemi COVID-19.

Variabel yang dilibatkan dalam studi berikut yaitu Kualitas Pelayanan $\left(X_{1}\right)$ Citra Merek $\left(\mathrm{X}_{2}\right)$ Electronic Word of Mouth $\left(\mathrm{X}_{3}\right)$ merupakan variabel bebas dan Kepuasan Pelanggan sebagai variabel terikat (Y). Pengumpulan data menggunakan metode kuesioner sebagai sumber data. Kuesioner dirancang menggunakan skala likert dengan 5 kategori yaitu Sangat setuju dengan poin 5, Setuju dengan poin 4, Ragu-ragu dengan poin 3, Tidak setuju dengan poin 2, Sangat tidak setuju dengan poin 1. Kuesioner yang dipakai telah melalui uji validitas 
dan reliabilitasnya dan memperoleh skor validitas 0,811 dan skor reliabilitas 0,875 sehingga dinyatakan memenuhi asumsi validitas dan reliabilitas

Data hasil penelitian diuji menggunakan bantuan SPSS 24.0 dan dianalisis dengan memakai analisis deskriptif dan analisis regresi linier berganda. Data dianalisis regresi berganda karena berdasarkan paradigma yang dibangun tidak ada keterkaitan atau korelasi antar variabel bebas. Persamaan regresi linier berganda menurut regresi linier berganda dapat dipakai untuk mendapatkan ilustrasi tentang impak variabel bebas yang ditujukkan pada variabel terikat. Adapun persamaan garis regresinya yang membentuk formula, yakni:

$$
Y=\alpha+\beta_{1} X_{1}+\beta_{2} X_{2}+\beta_{3} X_{3}+\varepsilon
$$

Keterangan:

$\mathrm{Y}=$ Kepuasan Pelanggan

$\alpha=$ Bilangan konstanta

$B_{1}=$ Koefisien regresi dari Kualitas Pelayanan

$B_{2}=$ Koefisien regresi dari Citra Merek

$B_{3}=$ Koefisien regresi dari Electronic Word of Mouth

$\varepsilon=$ Kesalahan Prediksi (error)

Sebelum dilakukan pengujian hipotesis sebelumnya dilaksanakan pengujian terhadap asumsi penelitian melalui pengujian normalitas, multikolinearitas dan heteroskedastisitas.

Uji normalitas ini dipakai dalam melakukan pengujian apakah pada model regresi, variabel pengganggu/residual atau variabel terikat dan bebas mempunyai distribusi normal (Ghozali, 2011). Pengujian normalitas lain yang lebih mumpuni dilaksanakan yakni melalui analisis statistic. Hal ini dipakai untuk melakukan pengujian terhadap normalitas residual sebuah model regresi yakni dengan memakai uji KolmogorovSmirnov (K-S). Uji multikolinearitas dilakukan guna melakukan pengujian terhadap model regresi apakah ditetapkan adanya korelasi antar variabel bebas (independen). pengujian multikokunearitas utnuk mengetahui ada aau tidaknya multikolinearitas di dalam model regresi mampu diperhatikan melalui: (1) nilai Tolerance dan (2) Variance Inflation Factor (VIF). Uji heteroskedastisitas bertujuan untuk menguji apakah dalam model regresi terjadi ketidaksamaan variance dari residual satu pengamatan kepengamatan yang lain(Ghozali, 2011). Jika variance dari residual dari satu pengamatan yang lain tetap, maka disebut homoskedastisitas dan jika berbeda disebut heteroskedastisitas. Pengujian heteroskedastisitas menggunakan Uji Glejser. Koefisien determinasi mencari tahu bagaimana kecakapan model dalam menjabarkan variasi variabel terikat. Nilai koefisiensi determinasi adalah antara nol dan satu. Nilai $R^{2}$ yang kecil berarti kecakapan variabel-variabel bebas dalam urusannya dengan menjelakan variasi variabel terikat amat terbatas. Pada penelitian ini, koefisien determinasi yang digunakan yakni nilai dari Adjuset $\mathrm{R}^{2}$ yang disebabkan oleh nilai Adjuset $\mathrm{R}^{2}$ mampu bertambah atau berkurang jika variabel ditambahkan kedalam model (Ghozali, 2011).

\section{Hasil dan Pembahasan}

Partisipan pada studi ini merupakan 150 orang pelanggan Grab Food yang melakukan pembelian makanan menggunakan Grab Food pada masa pandemi COVID-19. Jabaran umum dari studi ini meliputi hasil analisis deskriptif data pada masing-masing aspek. Pada statistik deskriptif tersebut, akan dijabarkan berbagai langkah penjelasan kelompok dari skor minimal, skor maksimal, rata-rata, dan standar deviasi. Hasil analisis deskriptif studi ini dapat diamati melalui Tabel 1 di bawah ini. 
Tabel 1. Hasil Analisis Deskriptif

\begin{tabular}{lccccc}
\hline \multicolumn{1}{c}{ Variabel Penelitian } & $\mathrm{N}$ & $\begin{array}{c}\text { Skor } \\
\text { Minimal }\end{array}$ & $\begin{array}{c}\text { Skor } \\
\text { Maksimal }\end{array}$ & $\begin{array}{c}\text { Rata- } \\
\text { Rata }\end{array}$ & $\begin{array}{c}\text { Standar } \\
\text { Deviasi }\end{array}$ \\
\hline Kualitas Pelayanan $\left(\mathrm{X}_{1}\right)$ & 150 & 15 & 25 & 20,19 & 2,849 \\
Citra Merek $\left(\mathrm{X}_{2}\right)$ & 150 & 9 & 15 & 12,06 & 1,894 \\
Electronic Word of Mouth $\left(\mathrm{X}_{3}\right)$ & 150 & 24 & 40 & 32,22 & 4,209 \\
Kepuasan Pelanggan $(\mathrm{Y})$ & 150 & 12 & 20 & 16,09 & 2,360 \\
\hline
\end{tabular}

Merujuk ke Tabel 1, mampu dihasilkan 4 deskripsi umum hasil hasil studi yakni 1) Variabel Kualitas Pelayanan (X1) memiliki skor minimal 15, maksimal 25, rata-rata 20,19, berstandar deviasi 2,849. Itu berarti terdapat perbedaan skor Kualitas Pelayanan yang ditujukan pada skor rata-rata sebesar 2,849. 2) Variabel Citra Merek (X2) memiliki skor minimal 9 , maksimal 15, rata-rata 12,06, dan berstandar deviasi 1,894. Itu berarti terdapat perbedaan skor Citra Merek terhadap skor rata-rata sebesar 1,894. 3) Variabel Electronic Word of Mouth (X3) memiliki skor minimal 24, maksimal 40, rata-rata 32,22, dan berstandar deviasi 4,209ltu berarti terdapat perbedaan skor Electronic Word of Mouth terhadap skor rata-rata sebesar 4,209. 4) Variabel Kepuasan Pelanggan ( $Y$ ) memiliki skor minimal 12, maksimal 20, rata-rata 16,09, dan berstandar deviasi 2,360. Itu berarti terdapat perbedaan skor Kepuasan Pelanggan terhadap skor rata-rata sebesar 2,360.

Tabel 2. Hasil Uji Normalitas

\begin{tabular}{ll}
\hline Test Statistic & 0,060 \\
Asymp. Sig. (2-tailed) & 0,200 \\
\hline
\end{tabular}

Merujuk pada Tabel 2. mampu dilihat bahwa nilai Test Statistic sebesar 0,060 dengan nilai Asymp. Sig. (2-tailed) sejumlah 0,200 yang nilainya > 0,05 yang berarti dapat disimpulkan nilai residual berdistribusi secara normal.

Tabel 3. Ringkasan Hasil Uji Multikolinearitas

\begin{tabular}{|c|c|c|c|}
\hline \multirow[t]{2}{*}{ Model } & \multicolumn{2}{|c|}{$\begin{array}{c}\text { Collinearity } \\
\text { Statistics }\end{array}$} & \multirow[t]{2}{*}{ Keterangan } \\
\hline & Tolerance & VIF & \\
\hline Kualitas Pelayanan $\left(\mathrm{X}_{1}\right)$ & 0,987 & 1,013 & Bebas Multikolinearitas \\
\hline Citra Merek $\left(\mathrm{X}_{2}\right)$ & 0,990 & 1,011 & Bebas Multikolinearitas \\
\hline Electronic Word of Mouth $\left(\mathrm{X}_{3}\right)$ & 0,997 & 1,003 & Bebas Multikolinearitas \\
\hline
\end{tabular}

Berdasarkan Tabel 3, dapat diketahui bahwa seluruh variabel bebas memiliki value VIF $<10$ dan nilai tolerance $>0,10$, yang berarti mampu diartikan bahwa model bebas dari multikolinearitas.

Tabel 4. Hasil Uji Heteroskedastisitas

\begin{tabular}{|c|c|c|c|c|c|}
\hline \multirow[t]{2}{*}{ Model } & \multicolumn{2}{|c|}{$\begin{array}{l}\text { Unstandardized } \\
\text { Coefficients }\end{array}$} & \multirow{2}{*}{$\begin{array}{c}\begin{array}{c}\text { Standardized } \\
\text { Coefficients }\end{array} \\
\text { Beta }\end{array}$} & \multirow[t]{2}{*}{$t$} & \multirow[t]{2}{*}{ Sig. } \\
\hline & $B$ & Std. Error & & & \\
\hline (Constant) & 0,330 & 0,506 & & 0,653 & 0,515 \\
\hline Kualitas Pelayanan $\left(\mathrm{X}_{1}\right)$ & 0,010 & 0,015 & 0,056 & 0,680 & 0,498 \\
\hline Citra Merek $\left(X_{2}\right)$ & $-0,028$ & 0,023 & $-0,100$ & $-1,217$ & 0,226 \\
\hline Electronic Word of Mouth $\left(\mathrm{X}_{3}\right)$ & 0,014 & 0,010 & 0,115 & 1,403 & 0,163 \\
\hline
\end{tabular}

Berdasarkan data pada Tabel 4 mampu diamati bahwa setiap variabel bebas tidak berefek nyata secara statistik dalam memberikan impak ke variabel terikat nilai Absolut Residual (ABS_RES). Seluruh variabel memiliki probabilitas signifikansi yang lebih dari 0,05, yang berarti dapat dapat diartikan bahwa model regresi tidak memiliki heteroskedastisitas. Hal itu diakibatkan oleh data yang tersebar secara normal, tidak didapati adanya gejala 
multikolinearitas dan heteroskedastisitas sehingga mampu dilaksanakan tahap uji hipotesis memakai analisis regresi linear berganda. Didapatkan hasil pengujian hipotesis yang tertuang padapada Tabel 5.

Tabel 5. Hasil Analisis Regresi Linear Berganda

\begin{tabular}{|c|c|c|c|c|c|}
\hline \multirow[t]{2}{*}{ Model } & \multicolumn{2}{|c|}{$\begin{array}{l}\text { Unstandardized } \\
\text { Coefficients }\end{array}$} & \multirow{2}{*}{$\begin{array}{c}\text { Standardized } \\
\text { Coefficients } \\
\text { Beta }\end{array}$} & \multirow[t]{2}{*}{$t$} & \multirow[t]{2}{*}{ Sig. } \\
\hline & $B$ & Std. Error & & & \\
\hline (Constant) & $-7,780$ & 0,827 & & $-9,411$ & 0,000 \\
\hline Kualitas Pelayanan $\left(X_{1}\right)$ & 0,549 & 0,025 & 0,662 & 21,948 & 0,000 \\
\hline Citra Merek $\left(\mathrm{X}_{2}\right)$ & 0,635 & 0,038 & 0,509 & 16,902 & 0,000 \\
\hline $\begin{array}{l}\text { Electronic Word of Mouth } \\
\left(\mathrm{X}_{3}\right)\end{array}$ & 0,159 & 0,017 & 0,284 & 9,477 & 0,000 \\
\hline
\end{tabular}

Merujuk pada proses hitung regresi linear berganda di atas, diperoleh hasil persamaan regresi yakni.

$$
Y=-7,780+0,549 X_{1}+0,635 X_{2}+0,159 X_{3}+\varepsilon
$$

Merujuk pada model di atas, mampu diartikan bahwa 1) Konstanta -7,780 mengungkapkan bahwa jika variabel Kualitas Pelayanan $\left(\mathrm{X}_{1}\right)$, Citra Merek $\left(\mathrm{X}_{2}\right)$, dan Electronic Word of Mouth $\left(\mathrm{X}_{3}\right)$ memiliki value nol, itu berarti nilai variabel Kepuasan Pelanggan ( $\mathrm{Y}$ ) yakni sejumlah -7,780. 2)Koefisien regresi Kualitas Pelayanan $\left(X_{1}\right)$ sejumlah 0,549 yang dapat diartikan bahwa jika ada peningkatan Kualitas Pelayanan $\left(X_{1}\right)$ sejumlah 1 satuan, dapat diartikan Kepuasan Pelanggan $(Y)$ akan bertambah sejumlah 0,549 satuan. 3)Koefisien regresi Citra Merek $\left(X_{2}\right)$ sejumlah 0,635 yang artinya jika ada peningkatan Citra Merek $\left(X_{2}\right)$ sejumlah 1 satuan, itu berarti Kepuasan Pelanggan $(Y)$ akan bertambah sejumlah 0,635 satuan. 4) Koefisien regresi Electronic Word of Mouth $\left(X_{3}\right)$ sejumlah 0,159 yang dapat diartikan bahwa jika ada peningkatan Electronic Word of Mouth $\left(\mathrm{X}_{3}\right)$ sejumlah 1 satuan, itu berarti Kepuasan Pelanggan ( $Y$ ) akan bertambah sejumlah 0,159 satuan.

Tabel 6. Hasil Uji Hipotesis Secara Simultan

\begin{tabular}{llccccc}
\hline Model & & Sum of Squares & Df & Mean Square & $F$ & Sig. \\
\hline 1 & Regression & 721,048 & 3 & 240,349 & 322,452 & $0,000^{\mathrm{b}}$ \\
& Residual & 108,825 & 146 & 0,745 & & \\
& Total & 829,873 & 149 & & & \\
\hline
\end{tabular}

Dari Tabel 6 diketahui bahwa nilai signifikansi yakni 0,000 yang berarti $<0,05$ menyebabkan $\mathrm{H}_{0}$ tidak diterima yang juga mampu diartikan bahwa ada impak berkelanjutan yang tinggi dari variabel Kualitas Pelayanan $\left(X_{1}\right)$, Citra Merek $\left(X_{2}\right)$ dan Electronic Word of Mouth $\left(\mathrm{X}_{3}\right)$ kepada Kepuasan Pelanggan $(\mathrm{Y})$. Merujuk pada impak variabel Kualitas Pelayanan $\left(X_{1}\right)$, Citra Merek $\left(X_{2}\right)$ dan Electronic Word of Mouth $\left(X_{3}\right)$ yang seluruhnya menawarkan impak yang baik, sehingga secara simultan juga akan memberikan impak yang baik pada Kepuasan Pelanggan $(\mathrm{Y})$. Itu juga berarti bahwa $\mathbf{H}_{\mathbf{1}}$ diterima atau Kualitas Pelayanan $\left(X_{1}\right)$, Citra Merek $\left(X_{2}\right)$ dan Electronic Word of Mouth $\left(X_{3}\right)$ memiliki impak yang baik dan tinggi pada Kepuasan Pelanggan (Y).

Merujuk pada hasil uji statistik t yang telah dilaksanakan, dapat dikenali hasil pengujian hipotesisi kedua ketiga dan keempat. Proses uji hipotesis kedua $\left(\mathrm{H}_{2}\right)$ mampu diamati pada Tabel 4.9 yang menunjukkan nilai signifikansi variabel Kualitas Pelayanan $\left(X_{1}\right)$ sejumlah 0,000 $<0,05$, sehingga mampu ditetapkan bahwa variabel $X_{1}$ memiliki impak yang ditujukan kepada $Y$. Untuk nilai t positif menetapkan bahwa variabel $X_{1}$ memiliki kaitan yang sejalan dengan $Y$ sehingga mampu diartikan bahwa $\mathrm{H}_{2}$ diterima yakni Kualitas Pelayanan $\left(\mathrm{X}_{1}\right)$ memiliki impak yang baik dan tinggi pada Kepuasan Pelanggan (Y). 
Proses uji hipotesis ketiga $\left(\mathrm{H}_{3}\right)$ mampu diperhatikan di Tabel 4.9 bahwa value signifikansi Citra Merek $\left(\mathrm{X}_{2}\right)$ sejumlah $0,000<0,05$, sehingga mampu ditetapkan bahwa variabel $\mathrm{X}_{2}$ memiliki impak yang ditujukan pada $\mathrm{Y}$. Untuk nilai t positif dapat diartikan bahwa variabel $\mathrm{X}_{2}$ memiliki kaitan yang sejalan dengan $\mathrm{Y}$, sehingga mampu diartikan bahwa $\mathrm{H}_{3}$ diterima yakni Citra Merek $\left(\mathrm{X}_{2}\right)$ memiliki impak yang baik dan tinggi terhadap Kepuasan Pelanggan ( $\mathrm{Y}$ ).

Proses uji hipotesis keempat $\left(\mathrm{H}_{4}\right)$ mampu diamati di Tabel 4.9 bahwa nilai signifikansi variabel Electronic Word of Mouth $\left(X_{3}\right)$ sejumlah $0,000<0,05$, sehingga mampu ditetapkan bahwa variabel $X_{3}$ memiliki impak yang ditujukan pada $Y$. Untuk nilai t positif dapat diartikan bahwa variabel $X_{3}$ memiliki kaitan yang sejalan dengan $Y$, sehingga mampu diartikan bahwa $\mathrm{H}_{4}$ diterima yaitu Electronic Word of Mouth $\left(\mathrm{X}_{3}\right)$ memiliki impak yang baik dan tinggi terhadap Kepuasan Pelanggan (Y).

Tabel 7. Hasil Analisis Koefisien Determinasi

\begin{tabular}{cccc}
\hline $\mathrm{R}$ & $R$ Square & $\begin{array}{c}\text { Adjusted } R \\
\text { Square }\end{array}$ & $\begin{array}{c}\text { Std. Error of the } \\
\text { Estimate }\end{array}$ \\
\hline $0,932^{\mathrm{a}}$ & 0,869 & 0,866 & 0,863 \\
\hline
\end{tabular}

Berdasarkan Tabel 7, mampu diamati bahwa value dari Adjusted $R$ Square sejumlah 0,831 yang berarti variasi variabel Kualitas Pelayanan $\left(\mathrm{X}_{1}\right)$, Citra Merek $\left(\mathrm{X}_{2}\right)$, dan Electronic Word of Mouth $\left(\mathrm{X}_{3}\right)$ hanya dapat menjabarkan $86,6 \%$ variasi variabel Kepuasan Pelanggan $(Y)$. Untuk persentase $13,4 \%$ lainnya telah diberi pengaruh oleh aspek lain, selain yang diinvestigasi pada studi ini.

Proses uji hipotesis variable Kualitas Pelayanan yang ditujukan pada Kepuasan Pelanggan didapatkan hasil bahwa Kualitas Pelayanan memiliki impak yang baik dan tinggi pada Kepuasan Pelanggan. Untuk kualitas pelayanan, itu merupakan pemberian nilai oleh konsumen pada servis yang didapatkan. Untuk Kualitas Pelayanan juga mampu ditetapkan sebagai tingkat evaluasi yang didapatkan pelanggan jika disandingkan yang pelanggan beri untuk memperoleh barang atau jasa berdasarkan (Nastiti et al., 2019). Sedangkan Kualitas servis yang diinginkan oleh konsumen yakni mampu menawarkan tingkat rasa puas yang tinggi bagi konsumen sesuai dengan yang diperoleh. Konsumen tidak hanya memberi value dari hasil yang diperoleh namun juga dari proses pemberian produk tersebut (Noerchoidah, 2017)

Kualitas pelayanan Grab Food menurut pelanggan yang menggunakanya sudah sangat baik dilihat dari segi Driver Grab Food bersikap ramah dan sopan, mampu melayani konsumen dengan baik, secara cepat dan tidak berbelit-belit. Driver Grab Food juga selalu berpenampilan bersih dan rapi serta taat dalam menerapkan protokol kesehatan Covid-19. Pelayanan tesebut membuat pelanggan merasa puas dalam menggunakan layanan Grab Food. Dilihat dari playstore aplikasi Grab juga telah mendapatkan rating 4,4 bintang yang berarti sebagian besar pelangan merasa puas dan suka dengan pelayanan yang sudah diberikan.

Kualitas pelayanan telah mendapatkan tanggapan yang positif dari para pelanggan dikarenakan para driver Grab Food yang selalu berpakaian bersih dan rapi serta selalu menerapkan protokol kesehatan. Driver Grab Food juga mampu berkomunikasi dengan baik kepada pelanggan mulai dari tutur kata yang sopan dan sikap yang ramah. Keberhasilan dari kualitas layanan ini hendaknya ditingkatkan guna mencapai kepuasan pelanggan secara lebih optimal. Hal yang dapat dilakukan antara lain memberi seragam kepada driver Grab Food secara berkala agar seragam yang digunakan tetap terjaga warna dan kebersihannya dikarenakan harus digunakan setiap hari dalam bekerja. Pelanggan juga hendaknya diberikan produk tas ramah lingkungan dengan identitas Grab, selain dapat meningkatkan kualitas pelayanan juga dapat ikut dalam pelestarian lingkungan. Untuk produk makanan dan minuman yang hangat atau dingin, alangkah baiknya driver Grab Food juga diberikan kotak penghangat dan pendingin makanan agar makanan atau minuman yang dipesan pelanggan tetap terjaga suhunya ketika sampai di lokasi tujuan, apalagi untuk pelanggan dengan alamat tujuan yang jauh dari tempat mebelinya. Pemberian reward kepada pelanggan yang dalam kurun waktu 
tertentu menggunakan aplikasi Grab Food dengan jumlah pesanan tertentu juga baiknya dilakukan agar pelanggan memiliki keinginan lebih untuk menggunakan aplikasi Grab Food. Terlebih lagi kebanyakan pengguna aplikasi berdasarkan penelitian yang dilakukan peneliti adalah perempuan yang barang tentu lebih tertarik dengan reward contohnya seperti promo atau diskon produk tertentu dalam aplikasi.

Pelayanan yang memuaskan ini barang tentu menciptakan rasa puas pelanggan setelah menggunakan Grab Food ditambah lagi dengan situasi pandemi yang mengharuskan kita membatasi aktifitas diluar rumah. Yang diperoleh dari studi ini juga searah dengan hasil studi terdahulu yang dilaksanakan oleh Novianti, dkk. (2018) yang menyebutkan bahwa kualitas servis memberi impak yang baik terhadap rasa puas konsumen. Hal selaras juga didapatkan dari studi yang dilaksanakan oleh Shinta, dkk. (2019) dan (Nastiti et al., 2019), yang menetapkan kaitan kualitas pelayanan memiliki impak yang baik pada rasa puas konsumen.

Berdasarkan pengujian hipotesis variable Citra Merek terhadap Kepuasan Pelanggan diperoleh hasil bahwa Citra Merek berpengaruh positif dan signifikan terhadap Kepuasan Pelanggan. Citra dari sebuah produk baik barang dan jasa mampu memberikan persepsi tersendiri bagi konsumen (Nastiti et al., 2019). Citra merek juga mempunyai peluang untuk mencapai kepuasan pelanggan, dimana citra terhadap suatu merek dapat menjadi dasar pelanggan dalam melakukan pembelian hingga mencapai kepuasan pelanggan.

Grab Food bagi pelanggan merupakan jasa pengantaran makanan yang terkenal, dilihat dari yang sudah mendownload aplikasi Grab di playstore sudah lebih dari 100 juta kali download. Hal ini menandakan bahwa Grab Food sudah bukan merupakan hal yang asing di masyarakat. Dengan begitu banyak iklan tentang Grab Food baik di televisi maupun media sosial barang tentu keberadaan Grab Food sudah dikenal dengan baik oleh kebanyakan masyarakat khususnya generasi muda.

Selain brand yang telah dikenal luas, perusahaan Grab Food mempunyai kredibilitas yang memukai dan tidak perlu diragukan lagi. Pada masa pandemi Covid-19, Grab Food juga sering memberikan promo yang menarik. Promo ini tentu sangat bermanfaat, apalagi di saat seperti sekarang kita sering menggunakan jasa antar makanan dikarenakan aturan pembatasan kegiatan di luar rumah. Untuk lebih meningkatkan citra merek Grab Food bisa juga dengan pemberian tas makanan ramah lingkungan berisi identitas Grab Food kepada pelanggan, hal ini selain meningkatkan citra merek juga dapat menunjukan kredibilitas Grab sebagai perusahaan yang perduli akan lingkungan. Selain itu juga dapat dilakukan dengan peningkatan pengadaan kegiatan sosial, pembagian masker dengan logo Grab atau pemberian bantuan kepada masyarakat yang membutuhkan, apalagi dikondisi masa pandemi seperti sekarang dimana banyak masyarakat yang memerlukan masker atau bantuan sembako. Hal ini barang tentu dapat lebih meningkatkan citra merek yang bermuara pada peningkatan kepuasan pelanggan.

Citra merek Grab Food yang terkenal tentu akan membuat perusahaan semakin meningkatkan pelayanan dan semakin memperhatikan kemauan konsumen. Sehingga citra merek Grab Food memberikan impak yang tinggi pada rasa puas konsumennya. Studi ini turut selaras dengan hasil investigasi dilaksanakan oleh Setyowati dan Wiyadi (2016), Laila dkk (2017), Dianah dan Welsa (2017), Putra dan Suprihhadi (2018), dan (Nastiti et al., 2019) yang juga menyatakan bahwa citra merk memberikan impak yang baik dan tinggi pada rasa puas konsumen.

Berdasarkan pengujian kseimpulan sementara dari variable Electronic Word of Mouth terhadap Kepuasan Pelanggan diperoleh hasil Electronic Word of Mouth memberikan impak yang baik dan tinggi pada rasa puas konsumen. Itu mengindikasikan bahwa dengan adanya Electronic Word of Mouth, maka dapat mempengaruhi Kepuasan Pelanggan Grab Food. Electronic Word of Mouth merupakan suatu pengemukaan yang baik ataupun buruk yang dilaksanakan oleh konsumen yang memiliki potensi ataupun pelanggan terdahulu yang tidak menetap tentang barang atau tempat produksi, yang difokuskan untuk khalayak ramai atau badan khusus dari media daring (Hennig-Thurau et al., 2004). Electronic Word of Mouth mempunyai hubungan penting dalam kepuasan konsumen, karena penerimaan berita baik tentang layanan jasa maupun produk yang konsumen gunakan akan menyebabkan peningkatan kepuasan terhadap konsumen tersebut. 
Kebanyakan pelanggan percaya mengenai informasi tentang Grab Food yang terdapat pada media sosial. Informasi tentang Grab Food selain dapat diketahui melalui aplikasi Grab juga dapat diketahui dari iklan, postingan pelanggan di media sosial pribadinya atau dapat juga diketahui melalui ulasan pelanggan di Playstore. Di playstore pelanggan yang sudah memberikan ulasanya mencapai 6 juta ulasan serta banyak juga postingan-postingan di media sosial terkait bagaimana tanggapan mereka setelah memakai layanan Grab Food. Ketika mengalami ketidakpuasan dengan layanan Grab Food, ada yang mengungkapkannya di media sosial. Saat merasa puas dalam menggunakan layanan Grab Food ada juga yang menawarkan kepercayaan kepada pelanggan lain atau sekadar menyebarkan pengalaman dalam menggunakan layanan Grab Food pada media sosial. Maka dari itu tak jarang pelanggan mencari saran positif dan saran negatif terkait Grab Food pada media sosial.

Komentar, ulasan atau postingan positif dari para pengguna Grab Food tentunya akan membuat para pelanggan yang ingin mencoba menggunakan layanan Grab Food merasa lebih yakin untuk mencoba. Terdapat sebuah cara diantara lainnya untuk meningkatkan Electronic Word of Mouth bisa dengan mewajibkan driver Grab Food untuk meminta video tanggapan dari pelanggan setelah menerima layanan Grab Food dengan catatan apabila pelanggan tidak keberatan. Dimana video tangapan ini nantinya bisa diunggan di sosial media driver Grab Food_bersangkutan atau dapat diunggah melalui media sosial resmi milik Grab. Selain itu bisa dilakukan pembaruan aplikasi dimana ketika pesanan diterima pelanggan diwajibkan untuk langsung memberikan ulasan yang nantinya bisa dilihat oleh semua pengguna. Apalagi usia pelanggan kebanyakan pada usia kisaran 20 sampai 25 tahun yang barang tentu berada dalam usia yang melek teknologi yang sering aktif dalam media sosial.

Dengan adanya komentar, ulasan atau postingan positif ini juga menandakan bahwa pelanggan merasa puas setelah menggunakan layanan Grab Food, hal ini secara langsung mengindikasikan bahwa Electronic Word of Mouth mempengaruhi rasa puas konsumen Grab Food. Kesimpulan yang didapat juga selaras dengan hasil penelitian (Pasaribu \& Yuliawati, 2019) dan (Widyatmoko, Achmad, \& Wasil, 2018) yang turut menetapkan bahwa Electronic Word of Mouth memberi impak yang baik pada rasa puas konsumen.

Berdasarkan pengujian hipotesis variable Kualitas Pelayanan, Brand Image, dan Electronic Word of Mouth terhadap Kepuasan Pelanggan diperoleh hasil bahwa Kualitas Pelayanan, Brand Image, dan Electronic Word of Mouth secara berkesinambungan memberikan impak yang baik dan tinggi pada rasa puas konsumen. Hal ini mengindikasikan bahwa terdapatnya Kualitas Pelayanan, Brand Image, dan Electronic Word of Mouth yang mumpuni mampu menawarkan impak pada Kepuasan Pelanggan pengguna Grab Food. Selain itu, kualitas pelayanan Grab Food sudah sangat baik dilihat dari segi Driver Grab Food bersikap ramah dan sopan, mampu melayani konsumen dengan baik, secara cepat dan tidak berbelit-belit. Driver Grab Food juga selalu berpenampilan bersih dan rapi serta taat dalam menerapkan protokol kesehatan Covid-19. Grab Food bagi pelanggan juga merupakan jasa pengantaran makanan yang terkenal dan sudah bukan merupakan hal yang asing di masyarakat. Selain merek yang telah popular, perusahaan Grab Food memiliki kredibilitas yang baik dan tidak perlu diragukan lagi. Setelah menggunakan layanan dan pelanggan merasa puas dalam menggunakan layanan Grab Food banyak yang menawarkan kepercayaan produk kepada pelanggan lain atau sekadar menyebarkan pengalaman dalam menggunakan layanan Grab Food pada media sosial.

Untuk lebih meningkatkan kepuasan pelanggan perlu dilakukan peningkatan baik dari segi kualitas pelayanan, Brand Image, dan Electronic Word of Mouth secara serasi. Hal yang bisa dilakukan adalah dengan memberikan seragam secara berkala kepada driver Grab Food agar tetap terlihat rapi dan bersih, memberikan tas belanja ramah lingkungan dengan identisas Grab, mengadakan kegiatan sosial seperti pemberian masker gratis dengan identitas Grab atau pemberian bantuan sembako, dan driver bisa diberikan alat pemanas atau pendingin makanan agar suhu makanan tetap terjaga sampai di tangan pembeli. Driver Grab Food juga hendaknya rajin meminta tanggapan langsung dari pelanggan setelah selesai mengantarkan pesanan, baik berupa foto atau video yang nantinya bisa di unggah di media sosial pribadi atau media sosial resmi milik Grab. Dengan peningkatan kualitas pelayanan, Brand Image, dan Electronic Word of Mouth akan berdampak langsung pada peningkatan kepuasan 
pelanggan. Hal tersebut menandakan bahwa Kualitas Pelayanan, Brand Image, dan Electronic Word of Mouth secara bersama-sama berpengaruh terhadap kepuasan pelanggan.

Berdasarkan pemaparan diatas diperoleh bahwa Kualitas Pelayanan memberikan impak yang baik terhadap rasa puas konsumen. Berdasarkan hasil tersebut mengimplikasikan bahwa dengan adanya Kualitas Pelayanan yang baik pada suatu produk atau jasa, maka dapat menambah Kepuasan Pelanggan konsumen terhadap produk atau jasa tersebut. Cara untuk meningkatkan kualitas pelayanan seperti menjaga komunikasi yang baik dengan pelanggan, tepat waktu dalam melayani pelanggan, memberikan pelayanan terbaik, serta meningkatkan kualitas produk.

Citra Merek memberikan impak yang baik dan tinggi terhadap rasa puas konsumen. Merujuk pada hasil tersebut mengimplikasikan bahwa Brand Image yang mumpuni dapat menambah rasa puas konsumen dalam menggunakan produk atau jasa tersebut. Terdapat sebuah langkajh dalam menambah citra merek yakni melalui pembuatan iklan, kemasan produk atau hadiah dengan logo perusahaan atau dapat pula dengan melakukan kegiatan sosial yang membantu masyarakat khsusunya dimasa pandemi seperti saat ini.

Electronic Word of Mouth memiliki impak yang baik dan tinggi terhadap rasa puas konsumen. Berdasarkan hasil tersebut mengimplikasikan bahwa dengan adanya Electronic Word of Mouth yang positif dilakukan konsumen terhadap suatu produk atau jasa dapat berpengaruh pada peningkatan rasa puas konsumen terhadap produk tersebut. Untuk meningkatkan Electronic Word of Mouth dapat dilakukan dengan meminta komentar, saran atau masukan secara langsung dari pelanggan setelah menggunakan produk barang atau jasa yang ditawarkan baik melalui aplikasi yang dipunya perusahaan atau foto dan video yang nantinya bisa diunggah di media sosial perusahaan.

Kualitas Pelayanan, Brand Image, dan Electronic Word of Mouth memiliki impak yang baik dan tinggi terhadap rasa puas pelanggan. Berdasarkan hasil tersebut mengimplikasikan bahwa dengan adanya keserasian antara Kualitas Pelayanan, Brand Image, dan Electronic Word of Mouth dapat memberikan impak pada peningkatan rasa puas konsumen terhadap barang tersebut. Dimana barang dengan merek yang mempunyai citra yang baik, mempunyai pelayanan yang ramah dan Electronic Word of Mouth positif dari pelanggan akan dapat meningkatkan kepuasan konsumen dalam memakai produk atau jasa tersebut. Meningkatkan Kualitas Pelayanan, Brand Image, dan Electronic Word of Mouth secara bersama-sama tentu merupakan hal yang sangat baik bagi perusahaan. Hal yang dapat dilakukan adalah meningkatkan komunikasi dengan pelanggan, memperhatikan keinginan pelanggan, serta memberikan souvenir dengan identitas perusahaan ke pelanggan seperti masker, tas belanja ramah lingkungan atau sejenisnya yang dapat bermanfaat, pengadaan kegiatan sosial dan peningkatan iklan juga penting dilakukan oleh perusahaan.

Apabila perusahaan tidak dapat fokus meningkatkan Kualitas Pelayanan, Brand Image, dan Electronic Word of Mouth secara berkesinambungan dapat dilakukan dengan terlebih dahulu fokus pada satu variabel saja. Berdasarkan hasil penelitian variabel yang paling dominan memberikan impak terhadap rasa puas konsumen adalah citra merek. Apabila perusahaan sudah mempunyai nama yang baik dimata pelanggan barang tentu perusahaan akan mulai dapat melakukan peningkatan kualitas pelayanan, sehingga secara langsung berdampak pada kepuasan pelanggan dan keinginan pelanggan untuk berbagi pengalamannya setelah menggunakan produk barang atau jasa yang digunakan dikarenakan perusahaan sudah banyak dikenal dan mempunyai citra yang baik. Citra yang baik membuat pelanggan lebih yakin untuk menggunakan produk barang atau jasa yang ditawarkan.

Apabila perusahaan mengabaikan salah satu dari Kualitas Pelayanan, Brand Image, dan Electronic Word of Mouth tentu juga akan berdampak saling keterkaitan satu sama lain. Misalkan perusahaan tidak memperhatikan kualitas pelayanan maka akan berdampak pada penurunan kepuasan pelanggan. Jika banyak pelanggan merasa tidak puas atas pelayanan yang diberikan akan membuat citra perusahaan jelek dimata konsumen. Konsumen yang merasa tidak puas dapat berakibat pada postingan negatif konsumen di media sosial sehinga Electronic Word of Mouth yang didapatkan perusahaan juga negatif. Begitu pula apabila hal yang diabaikan adalah citra merek atau Electronic Word of Mouth akan berdampak kurang baik terhadap kepuasan pelanggan. Maka dari itu hendaknya untuk mencapai kepuasan 
pelanggan yang optimal perlu slalu menjaga dan meningkatkan Kualitas Pelayanan, Citra Merek dan Electronic Word of Mouth secara berkala dan berkesinambungan.

\section{Simpulan dan Saran}

Merujuk pada yang dihasilkan oleh analisis data serta penjabaran, sehingga dapat ditarik simpulan bahwa Kualitas Pelayanan, Brand Image, dan Electronic Word of Mouth memiliki impak yang baik dan tinggi terhadap rasa puas konsumen Grab Food. Kualitas Pelayanan memiliki impak yang baik dan tinggi terhadap rasa puas konsumen Grab Food. Brand Image memiliki impak yang baik dan tinggi terhadap rasa puas konsumen Grab Food. Electronic Word of Mouth memiliki impak yang baik dan tinggi terhadap rasa puas konsumen Grab Food.

Adapun saran yang mampu diberikan oleh peneliti yang berkesinambungan dengan kelanjutan penelitian ini, adalah sebagai berikut: Bagi produsen produk atau jasa, hasil studi ini dipakai sebagai preferensi dalam upaya meningkatkan Kepuasan Pelanggan. Beberapa hal yang dapat dilakukan untuk meningkatkan Kepuasan Pelanggan seperti menjaga dan meningkatkan Kualitas Pelayanan, menjaga Citra Merek agar tetap bisa bersaing serta melakukan pengamatan dan evaluasi dari Electronic Word of Mouth pelanggan guna melihat hasil pelayanan atau masukan dari pelanggan. Bagi mahasiswa atau peneliti lain, hasil studi berikut dapat dipakai sebagai kajian pustaka dalam melaksanakan studi terkait, dan dapat dikembangkan lagi dengan memakai variabel-variabel lain yang mampu memberikan impak terhadap Kepuasan Pelanggan. Bagi universitas, hasil penelitian ini diharapkan dapat digunakan sebagai acuan serta sumber ajar pada mata kuliah tertentu, serta dapat digunakan sebagai rekomendasi dalam memperkaya kajian pustaka.

\section{Daftar Pustaka}

Bahtiar, Laba, A. R., \& Jusni. (2019). The Effects of Marketing Mix and Service Quality on the Satisfaction and Loyalty of Customers at Mobile Business in Makassar (A Case Study on Telkomsel Customers in Makassar). International Journal of Science and Research (IJSR), Volume 8(1).

Ferrinadewi, E. (2008). Merek dan Psikologi Konsumen, Implikasi pada Strategi Pemasaran. Yogyakarta: Graha IImu.

Ghozali, I. (2011). Aplikasi Analisis Multivariate Dengan Program SPSS. Semarang: Badan Penerbit Universitas Diponegoro.

Hennig-Thurau, T., Gwinner, K. P., Walsh, G., \& Gremler, D. D. (2004). Electronic word-ofmouth via consumer-opinion platforms: what motivates consumers to articulate themselves on the Internet? Journal of Interactive Marketing, Vol. 18(No. 1), 38-52.

Irawan, H. (2010). Prinsip Kepuasan Pelanggan, Paradigma Baru Merebut Hati Pelanggan Untuk Memenangkan Persaingan. Jakarta: Gramedia.

Kotler, \& Philip. (2001). Manajemen Pemasaran di Indonesia: analisis, Perencanaan, Implementasi dan Pengendalian. Jakarta: Salemba Empat.

Lahap, J., Ramli, N. S., Said, N. M., Radzi, S. M., \& Zain, R. A. (2016). A Study of Brand Image towards Customer's Satisfaction in the Malaysian Hotel Industry. Journal Social and Behavioral Sciences 224 (2016), 149 - 157.

Lin, R. J., Chen, R. H., \& Chiu, K. K. . (2010). Customer relationship management and innovation capability:an empirical study. Industrial Management \& Data Systems, Vol. 101(No. 1), 111-133.

Martina, M., \& Sitio, A. (2019). The Effect of The Quality of Service, Products \& Promotions on the Purchase Decision of Simpati Card \& It's Impact on the Satisfaction of Telkomsel Customers in Kupang City. International Journal of Science and Research (IJSR), Volume 8(Issue 7, July 2019).

Nainggolan, F., \& Hidayat, A. (2020). The Effect Of Country Of Origin, Brand Image, Price Fairness, And Service Quality On Loyalty Toward IPhone Mobile Users, Mediated By 
Consumer Satisfaction. European Journal of Business and Management Research, Vol. 5(No. 1).

Nastiti, A., Rahayu, S., \& Astuti, T. (2019). Pengaruh Persepsi Harga, Kualitas Layanan Dan Citra Merek Terhadap Kepuasan Pelanggan Dan Dampaknya Terhadap Loyalitas Pelanggan Taksi New Atlas Di Kota Semarang. Diponegoro Journal Of Management, Volume 8(No 1), 126-136.

Noerchoidah. (2017). Pengaruh Kualitas Pelayanan Terhadap Kepuasan Pelanggan (Studi Orenztaxi) di Surabaya. Jurnal BISMA, Bisnis Dan Manajemen, Volume 9(Nomor 2).

Parasuraman, Z., \& Berry. (1988). SERVQUAL: A Multiple-Item Scale for Measuring Consumer Perception of Service Quality. Journal of Retailing. Marketing Science Institute, 1(64), 12-40.

Pasaribu, K. V, \& Yuliawati. (2019). Pengaruh Dimensi Electronic Word of Mouth Terhadap Keputusan Berkunjung dan Kepuasan Konsumen. Jurnal Manajemen Dan Bisnis Dewantara, Vol. 2(No. 2).

Ratri, L. E. (2007). Strategi Memenangkan Persaingan Pasar. Jakarta: Salemba Empat.

Sugiyono. (2011). Metode Penelitian Kuantitatif, Kualitatif dan R\&D. Bandung: Afabeta.

Widyatmoko, A., Achmad, G. N., \& Wasil, M. (2018). Pengaruh e-servqual, e-marketing dan e-wom terhadap kepuasan pelanggan. (Jurnal Seminar Nasional 2018 Fakultas Ekonomi dan Bisnis Universitas Mulawarman). 